\title{
THE NUCLEIC ACID AND CARBOHYDRATE CONTENT OF INFLUENZA VIRUS A AND OF VIRUS FRACTIONS PRODUCED BY ETHER DISINTEGRATION
}

\author{
BY W. FRISCH-NIGGEMEYER AND L. HOYLE
}

The Public Health Laboratory, Northampton

(With 4 Figures in the Text)

Early estimations of the nucleic acid content of influenza virus A gave values of the order of $5 \%$ and indicated the probable presence of both ribonucleic acid (RNA) and deoxyribonucleic acid (DNA) (Taylor, 1944; Knight, 1947; Graham, 1950).

The early results are of doubtful accuracy, since some of the work was done with inadequately purified virus, the quantity of nucleic acid was determined by phosphorus estimations which tend to be unreliable because of the high phospholipid content of the virus, and the type of nucleic acid was determined by the use of colour reactions for ribose and deoxyribose which proved unsatisfactory with virus preparations. More recently Ada \& Perry (1954b) estimated the total nucleic acid as $0.78 \%$ and suggested that only ribonucleic acid was an integral part of the virus.

Hoyle (1950, 1954) and Wyckoff (1953) brought evidence to show that the infective virus particle was essentially a fragment of the cytoplasm of the infected cell, and that the fundamental virus unit must be contained within the infective unit. From studies of virus multiplication in the fertile egg, Hoyle (1948, 1950, 1952) suggested that the fundamental virus unit is the complement-fixing soluble antigen, which appears in the infected cell before any increase in infective virus, and that this unit is ribonucleoprotein. Ada and Perry (1954a) prepared antigenantibody complexes by precipitating purified soluble antigen from infected chick embryo lungs with specific antibody and showed that the complex contained predominantly RNA. A small amount of DNA was found but was believed not to be an integral part of the antigen.

Hoyle $(1950,1952)$ showed that the infective virus particle could be disintegrated by ether treatment with the release of separate haemagglutinating and complement-fixing particles. The complement-fixing unit was apparently identical with the soluble antigen found in infected tissues, and, by the use of virus labelled with radiophosphorus, Hoyle, Jolles \& Mitchell (1954) showed that it carried the whole of the virus nucleic acid. The haemagglutinating particle was apparently a nucleic acid-free enzyme.

This paper describes the chemical analysis, with special reference to nucleic acid and carbohydrate, of purified influenza virus and of the haemagglutinin and soluble complement-fixing antigen produced when the infective particle is disintegrated by ether treatment. 


\section{Preparation of purified infective virus}

The most satisfactory method of preparing pure influenza virus consists in preliminary purification by adsorption and elution from red cells followed by differential centrifugation. It is impossible to prepare pure virus directly from infected allantoic fluid by differential centrifugation alone. The process of virus growth in eggs is associated with considerable desquamation of chorio-allantoic membrane cells into the fluid and subsequent disintegration of the cells. Cell counts of allantoic fluid at the peak of virus growth indicate the presence of about 2 million intact cells per $\mathrm{ml}$. and about equal numbers of cell nuclei in various stages of disintegration. Observations of the disintegration of such cells in the dark field microscope show that fragmentation of cell nuclei occurs with the release of particles of the same order of size as the virus. Such particles may be expected to contain DNA, and virus preparations made by differential centrifugation alone will therefore be heavily contaminated with DNA-containing nuclear fragments.

The difficulty can be overcome by the use of preliminary adsorption and elution of the virus from red cells, but at least 2 cycles of adsorption-elution must be used. At the first red cell adsorption the deposited red cells carry down desquamated cells and cell fragments from the allantoic fluid and during the process of elution much cell disintegration occurs, probably as a result of the action of proteolytic enzymes derived from the cell fragments. As a result the first cycle eluate contains haemoglobin, DNA derived from cell nuclei, and RNA from red cell and leucocyte cytoplasm. Ultraviolet adsorption spectra of first cycle eluates show very strong adsorption, especially in the region of $2600 \mathrm{~A}$. This ultraviolet adsorption is not due to virus nucleic acid since it is not removed by adsorption of the preparation with red cells. Second cycle eluates contain much less haemoglobin and do not show much adsorption of ultraviolet light in the $2600 \mathrm{~A}$. region.

As a result of these observations the following method of preparing purified virus has been adopted and has given very satisfactory results.

Virus was grown in the allantoic sac of 12-day-old fertile eggs and the allantoic fluid harvested at the time of maximum haemagglutinin titre. The virus was then concentrated 15 times by adsorbing with $1.5 \%$ chick or guinea-pig red cells, washing the cells twice with a volume of ice-cold saline equal to that of the original fluid, and eluting the virus by $2 \mathrm{hr}$. incubation at $37^{\circ} \mathrm{C}$. into one-fifteenth of the original volume of saline. (Theoretically guinea-pig red cells should be superior to chick cells for this first cycle adsorption-elution, since they contain no nuclei and there is therefore less danger of contamination of the preparation by DNA. However, guinea-pig red cells haemolyse more readily than chick cells in first cycle eluates so that in practice a cleaner product results if chick cells are used.)

The concentrated first cycle eluate was then purified by a second adsorptionelution. Guinea-pig red cells were used and care was taken to remove the leucocyte layer during preparation of the washed red cells. The first cycle eluate was adsorbed with $15 \%$ guinea-pig red cells. This amount was not quite sufficient to remove the whole of the virus, but a small loss of virus was accepted since it ensured that the 
red cells would be completely saturated with virus. The cells were washed three times with ice-cold saline and eluted into five times their volume of saline by $2 \mathrm{hr}$. incubation at $37^{\circ} \mathrm{C}$.

Second cycle eluates prepared in this way are relatively constant in virus content and properties. They are slightly opalescent and very faintly stained by haemoglobin. The haemagglutinin titre is $10-20,000$, the complement-fixing antigen titre is 32-64 and the preparations contain 1 part of virus in 10,000 to 1 in 5000 by dry weight. Preparations of pure intact virus and pure haemagglutinin and soluble antigen were prepared from the second cycle eluate as follows.

\section{Preparation of pure intact infective virus}

After a preliminary clarifying centrifugation for $30 \mathrm{~min}$. at an average centrifugal force of $5000 \mathrm{~g}$, the virus was sedimented by centrifugation in a Spinco centrifuge for one $\mathrm{hr}$. at an average centrifugal force of $26,000 \mathrm{~g}$. The deposited virus was suspended in approximately 10 volumes of saline and large particles removed by centrifugation at $5000 \mathrm{~g}$ for $10 \mathrm{~min}$.

\section{Ether fractionation of the virus and preparation of pure soluble antigen and haemagglutinin}

The second cycle eluate was mixed with half its volume of pure ethyl ether and shaken vigorously for 5 sec. It was then incubated at $37^{\circ} \mathrm{C}$. for $1 \mathrm{hr}$., again shaken for five seconds and incubated for a further $\mathrm{hr}$. The fluid was then centrifuged. A film of denatured protein accumulated at the ether-water interface. The aqueous layer was removed and incubated overnight in an open vessel to remove all traces of ether. $0.08 \%$ sodium azide was added to prevent bacterial growth during the overnight incubation. Soluble antigen and haemagglutinin were then separated by red cell adsorption. The fluid was adsorbed with $10 \%$ washed guinea-pig red cells, and then successively with $1 \%$ cells until the cells were no longer agglutinated. The final supernatant fluid constituted the soluble antigen fraction. The pooled agglutinated red cells were washed three times with ice-cold saline and the haemagglutinin eluted by four $\mathrm{hr}$. incubation at $37^{\circ} \mathrm{C}$., the cells being suspended in five times their volume of saline containing 1 in 10,000 calcium chloride and 50 Australian units of crystalline receptor-destroying enzyme (RDE) per ml. The RDE was added to accelerate the release of the haemagglutinin and ensure complete recovery. After removal of the cells by centrifugation the supernatant fluid constituted the haemagglutinin fraction.

As found in previous work the process of ether disintegration is associated with some loss of virus protein by denaturation. This loss tends to be greater with second cycle eluates than with first cycle eluates. The loss can be assessed by serological methods. The complement-fixing antigen titre of the original second cycle eluate (measured with a serum reacting only with soluble antigen) was 56, while that of the ether-treated preparation was 32, suggesting a loss of soluble antigen of about $40 \%$. Loss of haemagglutinin is more difficult to assess, since ether treatment increases the haemagglutinin titre as a result of virus disruption. However, an assessment can be made by determining the minimal amount of red cells 
which will completely adsorb the haemagglutinin. It required $20 \%$ red cells to adsorb the virus completely in the second cycle eluate, but only $12 \%$ was required to adsorb the haemagglutinin from the ether-treated preparation, again suggesting a loss of $40 \%$. Separation of soluble antigen and haemagglutinin was not quite complete. Serological tests of the two fractions gave the following results.
Soluble antigen fraction:
Complement-fixing antigen titre 32 Haemagglutinin titre
Haemagglutinin fraction:
Complement-fixing antigen titre Haemagglutinin titre 25,600

The soluble antigen fraction contained only one-thousandth of the total haemagglutinin but the haemagglutinin fraction still contained $5 \%$ of the total soluble antigen.

Both fractions were completely water clear and slightly stained by haemoglobin. They contained no material sedimentable at low speed and hence in the subsequent centrifugation no preliminary clarifying run was necessary. Both soluble antigen and haemagglutinin require centrifugation at an average centrifugal force of $100,000 \mathrm{~g}$ for 4 hours to bring about complete sedimentation. However, at this speed haemoglobin is partly sedimented and to avoid contamination it was found better to sediment the soluble antigen and haemagglutinin by centrifugation at $80,000 \mathrm{~g}$ for $6 \mathrm{hr}$. At this speed no appreciable haemoglobin was deposited. Serological tests on the $80,000 \mathrm{~g}$ supernatants showed that $90 \%$ sedimentation of both soluble antigen and haemagglutinin occurred.

The deposit from the soluble antigen fraction consisted of a very small transparent gelatinous pellet which resuspended readily in saline to give an almost clear fluid containing very little material sedimentable at $5000 \mathrm{~g}$.

The deposited haemagglutinin was more bulky, opaque and yellowish in colour, and less easily suspended. A somewhat larger amount of material could be removed by centrifugation at $5000 \mathrm{~g}$.

\section{Determination of the nucleic acid content of the preparations}

\section{Estimation and identification of nucleic acid}

Throughout this work nucleic acid has been detected and estimated by spectroscopy. A Barfit small quartz spectrograph was used equipped with a range of quartz cells containing $2 \mathrm{ml}$. of fluid, with light paths of 1,4 and $6 \mathrm{~cm}$. The ultraviolet light source was a hydrogen arc giving a continuous spectrum in the ultraviolet and a line spectrum in the visible range. With this equipment nucleic acid could be detected in a dilution of $1 / 240,000$.

In use a series of 12 spectra were taken on the same photographic plate with dilutions of the material ranging from $1 / 1$ to $1 / 48$ in equidistant logarithmic steps. By this means a direct photographic record of the ultraviolet light absorption of the material was obtained (figs. 1 and 2). A parallel series of spectra was taken with a standard solution of pure yeast RNA. Comparison with this standard enabled the purity of the material to be assessed and the concentration of nucleic acid determined to an accuracy of $\pm 6 \%$. The type of nucleic acid was identified by 


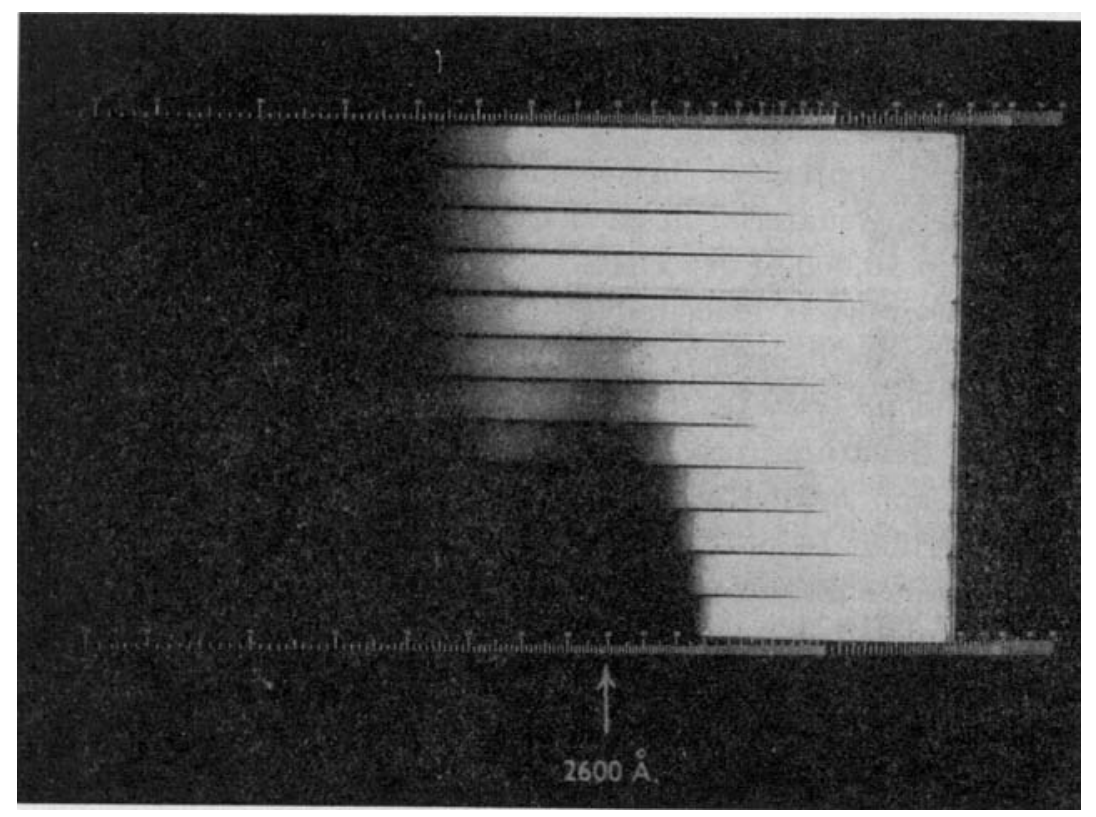

Fig. 1. Ultraviolet absorption of a solution of pure yeast ribonucleic acid. Dilutions from $1 / 1$ to $1 / 48$ in equidistant logarithmic steps. Hydrogen arc. Absorption cell volume $2 \mathrm{ml}$., light path $1 \mathrm{~cm}$. Standard solution containing $400 \mu \mathrm{g}$. in $2 \mathrm{ml}$.

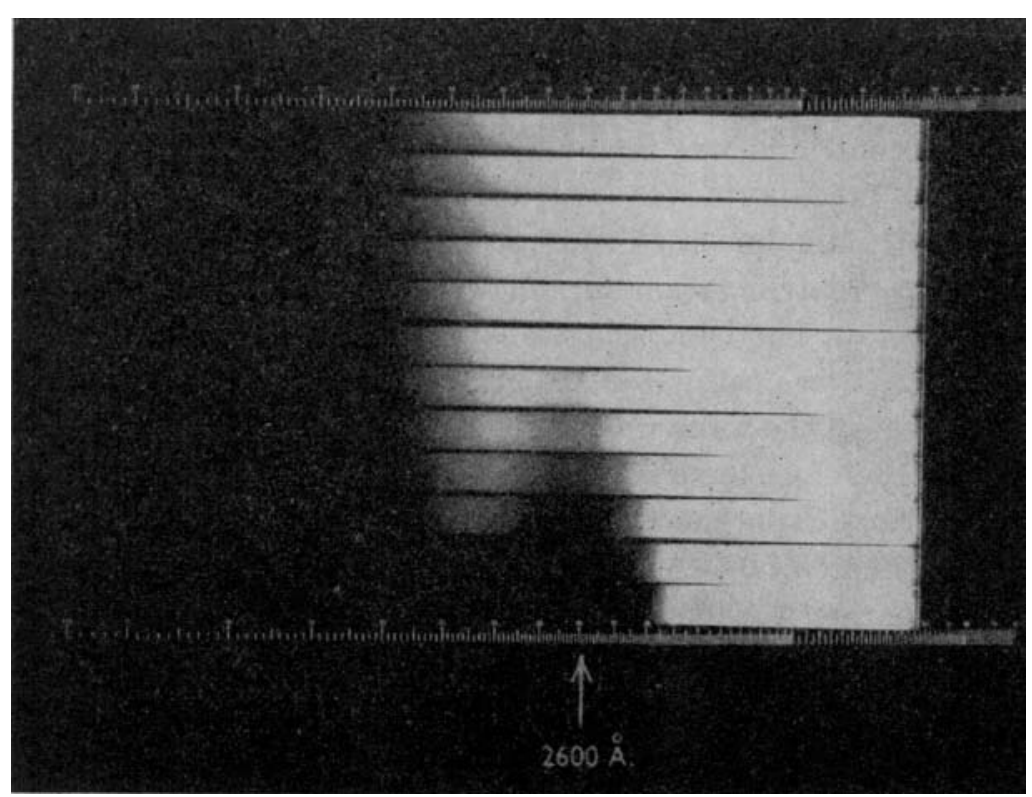

Fig. 2. Ultraviolet absorption of a solution of influenza virus soluble antigen nucleic acid: estimated by comparison with fig. 1 to contain $250 \mu \mathrm{g}$ of nucleic acid in $2 \mathrm{ml}$. 
hydrolysing the acid, separating the hydrolysis products by paper chromatography and detecting and photographing the spots by illumination in ultraviolet light of wavelength of 2537 A according to the method of Markham \& Smith (1949).

\section{Nucleic acid content of intact virus}

The nucleic acid content of intact virus was determined by two different methods, the starting material in each case being a second cycle eluate which contained 1 part in 10,000 of dry virus.

Method (1). The virus was deposited from $140 \mathrm{ml}$. of second cycle eluate by centrifugation at $26,000 \mathrm{~g}$ as described above. The deposited virus was suspended in $1 \mathrm{ml}$. of saline and precipitated by addition of 5 volumes of $96 \%$ ethanol. After standing $2 \mathrm{hr}$. the denatured precipitate was suspended in $2.0 \mathrm{ml}$. of $10 \%$ sodium chloride solution and heated at $100^{\circ} \mathrm{C}$. for $15 \mathrm{~min}$. The coagulated denatured protein was centrifuged out. An ultraviolet spectrogram of the supernatant indicated the presence of nucleic acid contaminated by protein. The supernatant was therefore reprecipitated by 2 volumes of ethanol and the deposit extracted with saline made slightly alkaline with sodium bicarbonate. Much material did not redissolve. After centrifugation an ultraviolet spectrogram was made of the supernatant. This showed apparently pure nucleic acid. By comparison with a standard solution of yeast RNA it was estimated that $100 \mu \mathrm{g}$. of nucleic acid was present. From this figure the nucleic acid content of the virus was estimated at $0.7 \%$.

Method (2). $108 \mathrm{ml}$. of second cycle eluate was used, the virus deposited by centrifugation and resuspended in $\mathbf{1} \cdot 0 \mathrm{ml}$. of saline. The $\mathrm{pH}$ was adjusted to 7.0 and $0.1 \mathrm{ml}$. of sodium dodecyl sulphate solution ( $5 \%$ in $45 \%$ ethanol) was added. The mixture was allowed to stand overnight. $50 \mathrm{mg}$. of solid sodium chloride was then added and after standing $5 \mathrm{hr}$. the deposited protein was removed by centrifugation. The supernatant fluid was then added to 2 volumes of $96 \%$ ethanol. After standing $3 \mathrm{hr}$. the precipitate was centrifuged out and extracted with $2.0 \mathrm{ml}$. of saline made slightly alkaline with sodium bicarbonate. After removal of undissolved protein by centrifugation an ultraviolet spectrogram was made. This showed an absorption band indistinguishable from that of yeast RNA, with a centre at $2600 \mathrm{~A}$. It was estimated that $80 \mu \mathrm{g}$. of nucleic acid was present. The nucleic acid content of the virus was therefore $0.74 \%$.

Both methods therefore gave similar results. In view of the small amounts of material a fairly large experimental error was possible, but the results would tend to confirm the estimate of $0.78 \%$ made by Ada and Perry (1954b) rather than the higher figures of earlier workers.

The two preparations of nucleic acid were pooled, dialysed free of salt, dried and hydrolysed with one drop of $\mathrm{N} / 1 \mathrm{HCl}$ at $100^{\circ} \mathrm{C}$. for $1 \mathrm{hr}$. A paper chromatogram was then run in isopropanol-HCl. The amount of nucleic acid available was too small for a perfectly satisfactory chromatogram, but on examination in ultraviolet light of wavelength $2537 \mathrm{~A}$ four adsorption spots were detected with $\mathrm{RF}$ values corresponding to guanine, adenine, cytidylic acid and uridylic acid. The material appeared therefore to be predominantly RNA. 


\section{Nucleic acid content of purified soluble antigen and haemagglutinin}

From $740 \mathrm{ml}$. of second cycle eluate, preparations of purified soluble antigen and haemagglutinin were prepared as described above. Serological tests indicated that the soluble antigen was free from haemagglutinin, but the haemagglutinin fraction contained $5 \%$ of the total soluble antigen.

The soluble antigen was deposited by centrifugation at $80,000 \mathrm{~g}$ and resuspended in $4.2 \mathrm{ml}$. of saline. The $\mathrm{pH}$ was adjusted to $7 \cdot 0$ and $0.42 \mathrm{ml}$. of $5 \%$ sodium dodecyl sulphate solution was added. After standing overnight $250 \mathrm{mg}$. of sodium chloride was added. The denatured protein was centrifuged out and retained-protein deposit (1). On addition of 2 volumes of ethanol the supernatant became opalescent but no precipitation of nucleic acid occurred. Sufficient acetone was therefore added to cause a precipitation of sodium chloride and this carried down the nucleic acid. The deposit was dried and dissolved in $2.0 \mathrm{ml}$. of distilled water. A small amount of denatured protein was removed by centrifugation-protein deposit (2). An ultraviolet spectrogram was then made of the clear supernatant, a parallel spectrogram being made with $400 \mu \mathrm{g}$. of yeast RNA (figs. 1 and 2). Both spectra were identical in form and it was estimated that the soluble antigen contained $250 \mu \mathrm{g}$. of nucleic acid. The protein deposits (1) and (2) were pooled and the nitrogen content determined by the micro-Kjeldahl technique. The preparations were found to contain $672 \mu \mathrm{g}$. of nitrogen. Assuming $15 \%$ of nitrogen to be present, this would correspond to $4.5 \mathrm{mg}$. of protein.

The soluble antigen appeared therefore to be a nucleoprotein containing $5 \cdot 3 \%$ of nucleic acid.

The nucleic acid after spectroscopic examination was dried in vacuo, dissolved in $0.4 \mathrm{ml}$. of distilled water and precipitated with $1.0 \mathrm{ml}$. of ethanol. The deposited nucleic acid was hydrolysed with $0.05 \mathrm{ml}$. of $\mathrm{N} / 1 \mathrm{HCl}$ for $1 \mathrm{hr}$. at $100^{\circ} \mathrm{C}$. A paper chromatogram was then run in isopropanol- $\mathrm{HCl}, 200 \mu \mathrm{g}$. of yeast RNA hydrolysate being run in parallel. The two chromatograms each showed 4 absorption spots in ultraviolet light, with RF values corresponding to guanine, adenine, cytidylic acid and uridylic acid (fig. 3).

It was concluded that the material was RNA and that the soluble antigen was a ribonucleoprotein containing $5.3 \%$ ribonucleic acid. Two later experiments gave values for the RNA content of $5 \cdot 2 \%$ and $5.5 \%$.

The haemagglutinin was analysed in the same manner as the soluble antigen. The denatured protein deposit contained $760 \mu \mathrm{g}$. of nitrogen corresponding to $5.1 \mathrm{mg}$. of protein. The nucleic acid content was found to be $15 \mu \mathrm{g}$. The haemagglutinin fraction therefore contained $5.6 \%$ of the total nucleic acid of the two fractions. Since it had been estimated by serological tests to contain $5 \%$ of the total soluble antigen it is clear that the haemagglutinin is nucleic-acid free and that the whole of the virus nucleic acid is contained in the soluble antigen.

As the haemagglutinin fraction contained $5 \%$ of soluble antigen the real protein content of the total soluble antigen was $4 \cdot 7 \mathrm{mg}$. while the haemagglutinin contained $4.9 \mathrm{mg}$. of protein. The virus particle would therefore appear to contain about equal amounts of soluble antigen and haemagglutinin protein. 
Carbohydrate content of virus and virus fractions

Taylor (1944) and Knight (1947) showed that influenza virus preparations contained carbohydrate other than nucleic acid sugar. By the use of the carbazole colour reaction Knight suggested that the carbohydrate was made up of galactose, mannose and glucosamine units.

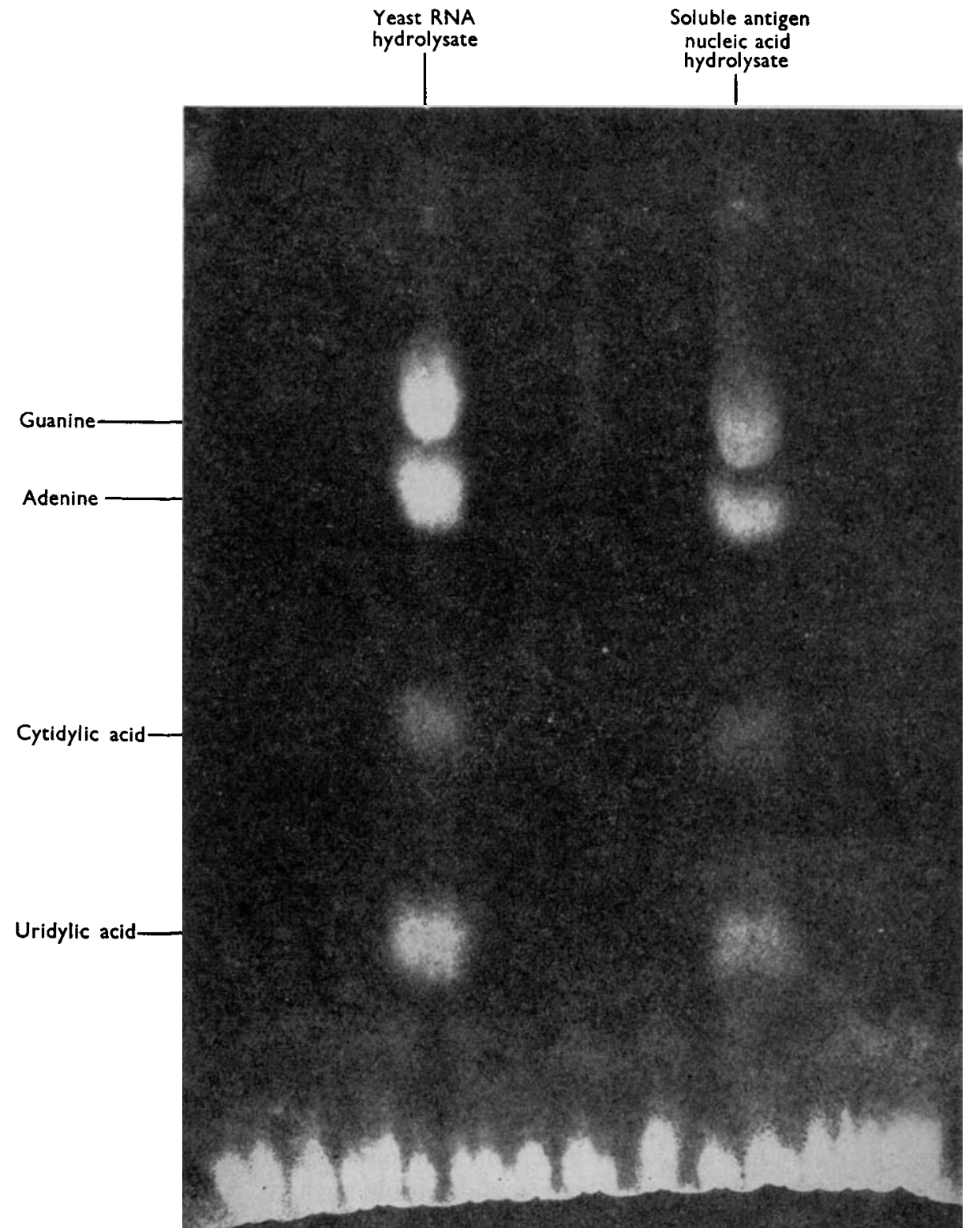

Fig. 3. Descending paper chromatogram in isopropanol-HCl of acid hydrolysates of pure yeast ribonucleic acid and influenza-virus soluble antigen nucleic acid. Photograph in monochromatic ultraviolet light wavelength $2537 \mathrm{~A}$. 
Preparations of purified intact virus, soluble antigen and haemagglutinin were made and the nitrogen content of the final saline suspensions was determined by the micro-Kjeldahl technique. The intact virus preparation contained $664 \mu \mathrm{g}$. of nitrogen per ml., the haemagglutinin contained $475 \mu \mathrm{g}$. per ml. and the soluble antigen $244 \mu \mathrm{g}$. per $\mathrm{ml}$.

Samples of the preparations were treated with carbazole and sulphuric acid by the method of Siebert \& Atno (1946); the colours developed were analysed in a Unicam D.G. absorptiometer, and compared with the curves given by standard solutions of glucose, galactose and mannose and mixtures of these sugars. The results are shown in fig. 4.
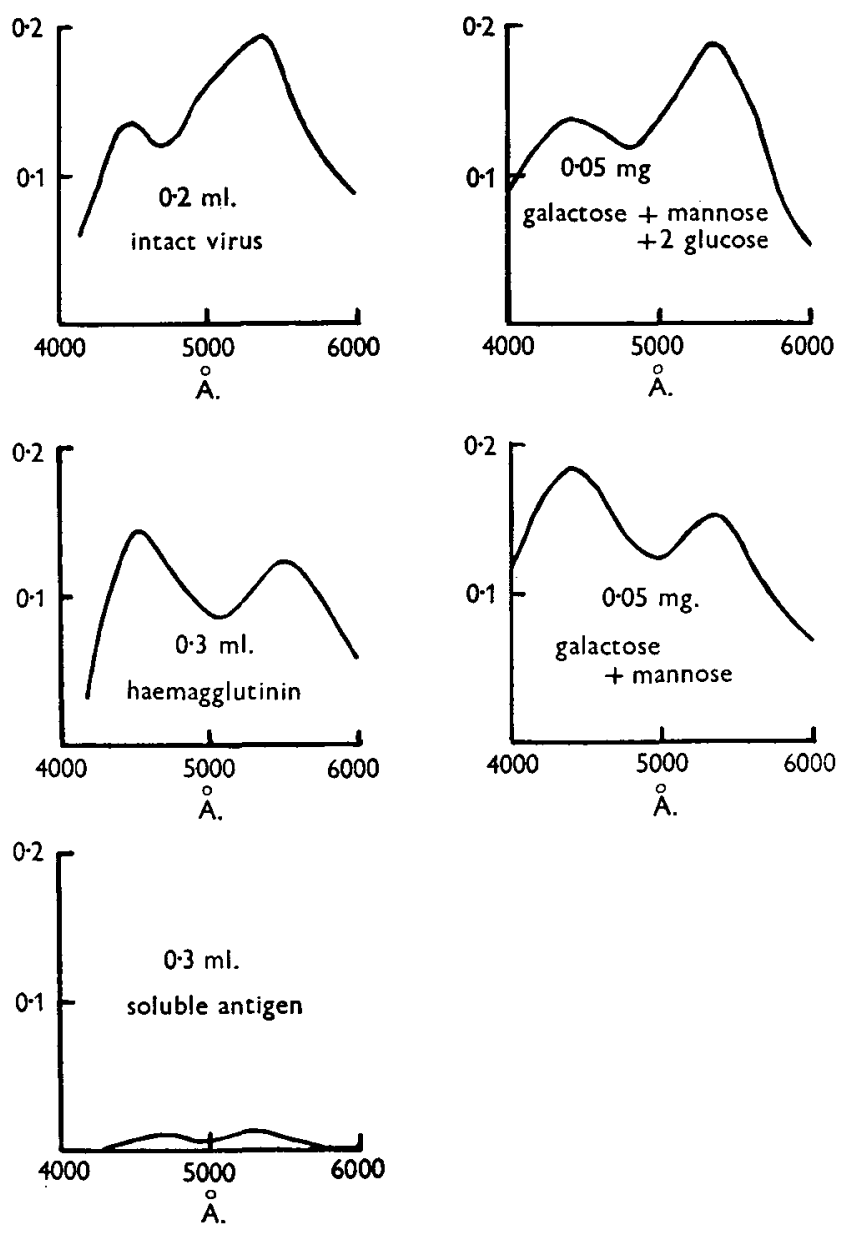

Fig. 4. Light absorption of coloured solutions obtained by the carbazole reaction with intact virus, haemagglutinin, soluble antigen and standard sugar mixtures.

\section{Carbohydrate content of intact virus}

The absorption curve obtained with intact virus was complex and could not be exactly matched by any simple mixture of sugars. The nearest match was given by a mixture of galactose, mannose and glucose in the molar proportions of $1: 1: 2$. 
With this curve as a standard the virus preparation was estimated to contain $250 \mu \mathrm{g}$. of carbohydrate per ml. The nitrogen content of intact virus was estimated as $9 \cdot 3 \%$ by the micro-Kjeldahl method. The virus therefore contains $3.5 \%$ carbohydrate.

\section{Carbohydrate content of haemagglutinin}

The absorption curve obtained with the haemagglutinin was almost exactly matched by that given by an equimolar mixture of galactose and mannose. With this curve as a standard the preparation was estimated to contain $140 \mu \mathrm{g}$. of carbohydrate per $\mathrm{ml}$. Assuming $15 \%$ of nitrogen in the haemagglutinin protein the result indicated that the haemagglutinin contained $4.2 \%$ carbohydrate. The haemagglutinin would therefore seem to be a mucoprotein containing $4.2 \%$ carbohydrate probably composed of galactose and mannose units.

\section{Carbohydrate content of the soluble antigen}

Only a trace of colour was given by the soluble antigen in the carbazole test and it was concluded that the antigen contained no carbohydrate other than the sugar component of the nucleic acid.

\section{DISCUSSION}

The primary object of this work was the chemical analysis of soluble antigen and haemagglutinin, since these seem to be fundamental units of virus protein with more constant properties than those of the infective particle.

The soluble antigen is a ribonucleoprotein containing $5 \cdot 3 \%$ of RNA. Electron microscopy of soluble antigen preparations (Hoyle, Reed \& Astbury, 1953) indicated a particle diameter of $120 \mathrm{~A}$ and this is supported by the results of centrifugation experiments. The molecular weight of the soluble antigen would therefore be of the order of 600,000 , and if the particle contains one molecule of RNA the molecular weight of RNA would be 32,000 , equivalent to $96-100$ nucleotides.

The whole of the nucleic acid of the infective virus particle appears to be carried by the soluble antigen (Hoyle, Jolles \& Mitchell, 1954). Since the infective virus contains $0.74 \%$ RNA the soluble antigen accounts for about $14 \%$ of the weight of the infective particle, and a spherical infective particle of diameter $100 \mathrm{~m} \mu$ and a particle weight of $3 \times 10^{8}$ would contain about 70 molecules of soluble antigen.

The haemagglutinin contains no nucleic acid and appears to be a mucoprotein containing $4 \cdot 2 \%$ of polysaccharide possibly composed of equimolar proportions of galactose and mannose.

Since the infective particle contains about equal amounts of soluble antigen and haemagglutinin protein and the particle size of the two is about the same, the infective virus particle probably contains about 70 particles of haemagglutinin. The haemagglutinin would account for $14 \%$ of the weight of the infective particle. As the infective virus contains $3.5 \%$ carbohydrate and the haemagglutinin $4.2 \%$ it is clear that haemagglutinin carbohydrate accounts for only one-sixth of the total virus carbohydrate. The carbazole reaction shows that the carbohydrate of intact virus is more complicated than that of the purified haemagglutinin. 
Soluble antigen and haemagglutinin together account for $28 \%$ of the weight of the infective virus. As the nitrogen content of infective virus is only $9 \cdot 3 \%$ the particle must contain about $38 \%$ of non-protein material (lipid and carbohydrate). The carbohydrate content being $3.5 \%$, the lipid content would be $34.5 \%$. Two recent estimates of the lipid content of standard virus by Uhler \& Gard (1954) gave values of 29 and $36 \%$. The infective virus must also contain about $34 \%$ of protein other than that contained in the soluble antigen and haemagglutinin. This protein is probably combined with the lipid and carbohydrate. Previous studies (Hoyle, $1952,1954)$ had indicated that the virus particle was developed by fragmentation of the cell cytoplasm and that it consisted of a closely packed aggregate of soluble antigen and haemagglutinin enclosed in a membrane derived from the cell wall. The chemical results would suggest that this membrane is composed of lipoprotein and mucoprotein. Treatment with ether denatures the lipoprotein and disrupts the particle. It is of interest that Schafer \& Zillig (1954) were able to disintegrate fowl plague virus by ether treatment with the release of a complement-fixing ribonucleoprotein and a haemagglutinin containing carbohydrate.

The relation between soluble antigen and haemagglutinin remains a fundamental problem of influenza virus chemistry. It is possible that influenza virus protein can exist in two states, as a ribonucleoprotein and as a mucoprotein. It may be suggested that the former represents the state in which the virus protein is synthesized in the cell, while the latter is an enzymically active form.

\section{SUMMARY}

The preparation of purified influenza virus from infected allantoic fluid is described, and its fractionation by ether treatment with the production of pure samples of soluble antigen and haemagglutinin.

Chemical analysis of intact infective virus showed it to have a nitrogen content of $9 \cdot 3 \%$, a carbohydrate content of $3.5 \%$, and a content of ribonucleic acid of $0 \cdot 7-0.74 \%$.

Purified soluble antigen derived from the infective virus particle was shown to be a ribonucleoprotein containing $5 \cdot 3 \%$ RNA. No carbohydrate other than ribose was found. Purified haemagglutinin was shown to be a mucoprotein containing $4.2 \%$ of a polysaccharide possibly composed of galactose and mannose in equimolar proportions.

The authors are indebted to the Medical Research Council for a grant in aid of expenses, and to Messrs Eli Lilly \& Co. for the generous provision of the Spinco centrifuge used in this work. The work was carried our during the tenure by one of us (W.F.-N.) of a British Council Fellowship. 


\section{REFERENCES}

Ada, G. L. \& Perry, B. T. (1954a). Studies on the soluble complement-fixing antigens of influenza virus. 3. The nature of the antigens. Austral. J. exp. Biol. 32, 177.

AdA, G. L. \& Perry, B. T. (1954b). The nucleic acid content of influenza virus. Austral. J. exp. Biol. 32, 453.

GrahaM, A. F. (1950). The chemical analysis of purified influenza virus A (PR8 strain) containing radioactive phosphorus. Canad. J. Res. 28, 186.

Hoyle, L. (1948). The growth cycle of influenza virus A. A study of the relations between virus, soluble antigen and host cell in fertile eggs inoculated with influenza virus. Brit. $J$. exp. Path. 29, 390.

HoYLe, L. (1950). The multiplication of influenza viruses in the fertile egg. J. Hyg., Camb., 48, 277.

Hoyle, L. (1952). Structure of the influenza virus. The relation between biological activity and chemical structure of virus fractions. J. Hyg., Camb., 50, 229.

Hoyle, L. (1954). The release of influenza virus from the infected cell. J. Hyg., Camb., 52, 180.

Hoyle, L., Jolles, B. \& Mitchell, R. G. (1954). The incorporation of radio-active phosphorus in the influenza virus and its distribution in serologically active virus fractions. J. Hyg., Camb., 52, 119.

Hoyle, L., Reed, R. \& Astbury, W. T. (1953). Electron microscope studies of the structure of influenza virus. Nature, Lond., 171, 256.

Kлгgнт, C. A. (1947). The nucleic acid and carbohydrates of influenza virus. J. exp. Med. $85,99$.

Markham, R. \& Smith, J. D. (1949). A technique for the identification and estimation of purine and pyrimidine bases, nucleosides, and related substances. Biochem. J. 45, 294.

Schafer, W. \& Zillig, W. (1954). Über den aufbau des virus-elementarteilchens der klassischen geflugelpest. I. Mitt.: Gewinnung, physikalisch-chemische und biologische eigenschaften einiger spaltprodukte. $Z$. Naturforschung, 12, 779.

Simbert, F. B. \& Atno, J. (1946). Determination of polysaccharide in serum. J. biol. Chem. $163,511$.

TAYLOR, A. R. (1944). Chemical analysis of influenza virus A (PR8 strain) and B (Lee strain) and swine influenza virus. J. biol. Chem. 153, 675.

UhLER, M. \& GARD, S. (1954). Lipid content of 'standard' and 'incomplete' influenza A virus. Nature, Lond., 173, 1041.

Wyckoff, R. W. G. (1953). Formation of the particles of influenza virus. J. Immunol. 70, 187.

(MS. received for publication 20. X. 55) 